\title{
PERFORMANCE ANALYSIS OF SOLAR COMBINED EJECTOR-VAPOR COMPRESSION CYCLE USING ENVIRONMENTAL FRIENDLY REFRIGERANTS
}

\author{
A. B. KASAEIAN AND S. DAVIRAN \\ Faculty of New Science and Technologies, University of Tehran, Iran. \\ akasa@ut.ac.ir
}

\begin{abstract}
In this study, a new model of a solar combined ejector-vapor compression refrigeration system has been introduced. The system has an addition with an internal heat exchanger to enhance the performance of the cycle. The effects of working fluid and operating conditions on the system performance including COP, entrainment ratio $(\omega)$, compression ratio (rp) and exergy efficiency were investigated. Some working fluids suggested are: R114，R141b，R123，R245fa，R600a，R365mfc，R1234ze(e) and R1234ze(z). The results show that R114 and R1234ze(e) yield the highest COP and exergy efficiency followed by R123, R245fa, R365mfc, R141b, R152a and R600a. It is noticed that the COP value of the new solar ejector-vapor compression refrigeration cycle is higher than that of the conventional ejector cycle with R1234ze(e) for all operating conditions. This paper also demonstrates that R1234ze(e) will be a suitable refrigerant in the solar combined ejector-vapor compression refrigeration system, due to its environmental friendly properties and better performance.
\end{abstract}

ABSTRAK: Kajian ini menganalisa model baru sistem penyejukan mampatan gabungan ejektor-wap solar. Sistem ini dilengkapi dengan penukar haba dalaman untuk meningkatkan prestasi kitaran. Kesan bendalir bekerja dan keadaan operasi pada prestasi sistem termasuk COP, nisbah pemerangkapan $(\omega)$, nisbah mampatan (rp) dan kecekapan eksergi telah disiasat. Beberapa bendalir bekerja yang dicadangkan adalah: R114, R141b, R123, R245fa, R600a, R365mfc, R1234ze(e) dan R1234ze(z). Hasil kajian menunjukkan R114 dan R1234ze(e) menghasilkan COP dan kecekapan eksergi tertinggi diikuti oleh R123, R245fa, R365mfc, R141b, R152a dan R600a. Didapati nilai COP kitaran penyejukan mampatan bagi ejektor-wap solar baru adalah lebih tinggi daripada kitaran ejektor konvensional dengan R1234ze(e) bagi semua keadaan operasi. Kertas kerja ini juga menunjukkan bahawa R1234ze(e) boleh menjadi penyejuk yang sesuai dalam sistem penyejukan mampatan gabungan ejektor -wap solar, kerana ianya mempunyai prestasi yang lebih baik serta sifatnya yang lebih mesra alam sekitar.

KEYWORDS: environmental friendly refrigerants; solar combined ejector-vapor compression cycle; R1234ze(e)

\section{INTRODUCTION}

Hydrofluorocarbon (HFC) refrigerants have been used over the last two decades to address the issue of ozone depletion associated with excess utilization of chlorofluorocarbon (CFC) and hydrochlorofluorocarbon (HCFC) refrigerants. While HFC refrigerants have no ozone depletion potential (ODP), many of them have relatively large values of global warming potentials (GWP) and, in fact, they comprise one of the six so-called "baskets of gases" contained in the Kyoto Protocol (1997). As a result, much effort is being invested in finding alternative refrigerants to conventional HFCs. The 
European Union's f-gas regulations (Regulation (EC) No 842/2006 and Directive 2006/40/EC) specify beginning on January 1, 2011 new models and on January 1, 2017 new vehicles fitted with air-conditioning cannot be manufactured with fluorinated greenhouse gases having global warming potentials (GWP) greater than 150 [1].

Dupont and Honeywell companies presented some information about a new refrigerant in the European Workshop on Mobile Air Conditioning \& Auxiliaries in Torino, Italy. This new refrigerant is a hydrofluro olefin as 2,3,3,3 tetrafluroprop_1_ene which is called as HFO-1234yf. This refrigerant has similar thermo physical properties to R134a hence major changes in equipment are not required. These refrigerants have the proper stability (chemical \& thermal) and compatibility values, have no observable corrosion effects on metals, and its properties are environmental friendly $(\mathrm{ODP}=0$, $\mathrm{GWP}=4, \mathrm{ALT}=11$ days and also proper LCCP) [2]. Brown et al., [3], demonstrates that R1234ze(z) deserves further consideration as a possible R-114 replacement. Huang, Chang et al., [4] developed a solar ejector cooling system using R141b as the refrigerant and obtained the overall $\mathrm{COP}$ of around 0.22 at a generating temperature of $95^{\circ} \mathrm{C}$, an evaporating temperature of $8^{\circ} \mathrm{C}$ and solar radiation of $700 \mathrm{~W} \mathrm{~m}^{-2}$. Bejan et al. [5] proposed using a booster and inter-cooler in an effort to improve the ejector cooling system with R114. In 2004, Arbel et al. [6] revised the system again with an HCFC refrigerant. The previous CFC refrigerant (R114) was replaced by R142b. Hydrofluoroether (HFE) was considered as a case study by Wolpert, Riffat et al. [7], for a solar powered ejector airconditioning system at a cosmetic factory in Mazunte, Mexico. Rusly, Charters et al. [8] combined ejector and vapor compression refrigeration systems. Refrigerant R152a was suggested to yield a good performance compared to other refrigerants such as ammonia, R245ca, R245fa and R500. Refrigerant R245fa was chosen by Rusly, Charters et al. [8] to be used in the ejector cycle of a combined ejector-vapor compression refrigeration system. Pridasawas and Lundqvist, [9] represented that, among natural refrigerants, normal butane is an interesting working fluid. Nehdi et al. [10] studied the performance of the solardriven ejector air conditioning with several environment-friendly working fluids. It appears that the refrigerant $\mathrm{R} 717$ offers the highest coefficient of performance (COP), for generator temperature $\mathrm{T}_{\mathrm{g}}=90^{\circ} \mathrm{C}$; condenser temperature $\mathrm{T}_{\mathrm{C}}=35^{\circ} \mathrm{C}$ and evaporator temperature $\mathrm{T}_{\mathrm{e}}=15^{\circ} \mathrm{C}$ with $\mathrm{R} 717$, the COP of ejector air-conditioning system is 0.408 . Jin Hua Wang et al. [11], showed that R365mfc can replace R141b as the working fluid of ejector cooling system at no pay-off of system performance as long as the ejector design is optimized.

In this study we present a new model of solar combined ejector-vapor compression refrigeration system using environmental friendly refrigerants like R1234yf in vapor compression cycle as a replacement of R134a, and R1234ze(e) as working fluids in ejector cycle. R1234ze(e) may be a suitable refrigerant to be used in the combined ejector-vapor compression cycle.

\section{ASSUMPTIONS AND METHODOLOGY}

The analysis in this paper is performed using a computer program developed in MATLAB. For purpose of extracting the necessary thermodynamic properties in the program, the REFPROP 8.0 software was linked with MATLAB. Figure 1a shows a schematic diagram of the conventional solar combined ejector- vapor compression refrigeration cycle and Fig. $1 \mathrm{~b}$ is the considered cycle in this study, which was developed using an internal heat exchanger after exiting the fluid from the ejector and before entering refrigerant to the generator. 


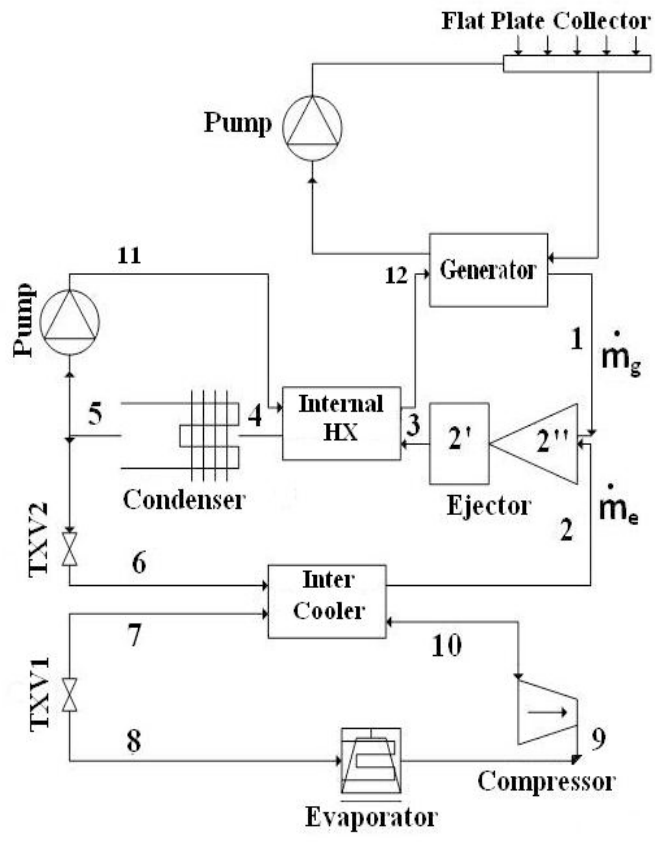

(a)

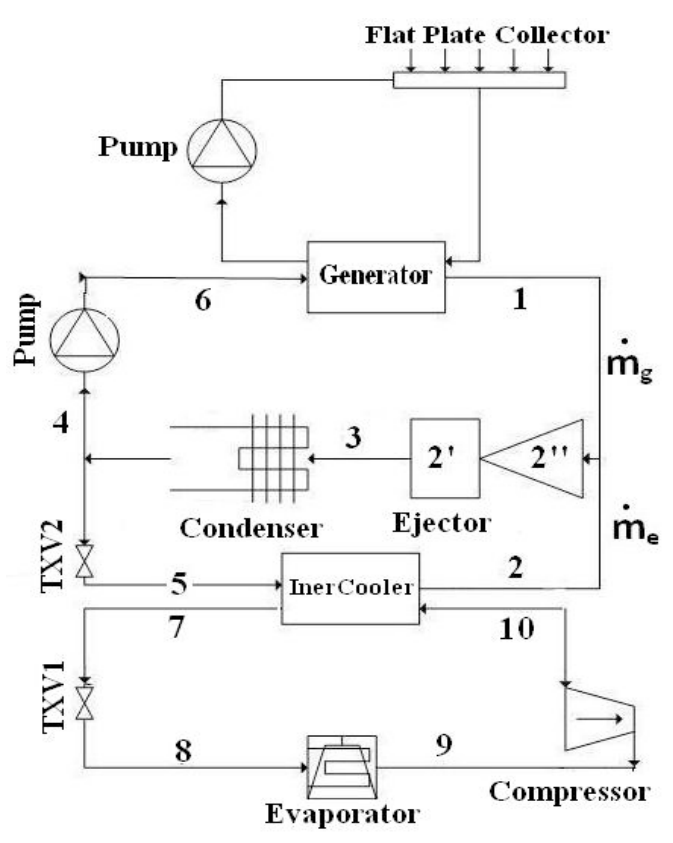

(b)

Fig. 1: (a) Schematic diagram of the conventional solar combined ejector-vapor compression refrigeration cycle. (Cycle 1); (b) Schematic diagram of the new solar combined ejector-vapor compression refrigeration cycle. (Cycle 2).

Some selected refrigerants, such as R114, R141b, R123, R245fa, R600a, R365mfc, R1234ze(e), and R1234yf were applied to simulate the solar driven ejector-vapor compression.

The following assumptions were made:

- The pressure drop in the heat exchangers is neglected,

- The incident solar radiation is $800 \mathrm{Wm}^{-2}$,

- A double-glazed flat-plate solar collector is used, $\mathrm{F}_{\mathrm{R}}(\tau \alpha)_{\mathrm{e}}=0.8$ and $\mathrm{F}_{\mathrm{R}} \mathrm{U}_{\mathrm{L}}=1.5 \mathrm{Wm}^{-}$ ${ }^{2} \mathrm{~K}^{-1}$, with an area of $60 \mathrm{~m}^{2}$,

- Water is used as the heating medium between the solar collector and the generator,

- The ambient air temperature is $30{ }^{\circ} \mathrm{C}$ which also is used as the reference temperature for the analysis,

- Water inlet temperature is $43^{\circ} \mathrm{C}$,

- The generating temperature is $95^{\circ} \mathrm{C}$,

- The condensing temperature is $55^{\circ} \mathrm{C}$,

- The evaporating temperature is $4{ }^{\circ} \mathrm{C}$,

- The generated fluid is superheated to $5 \mathrm{~K}$ more than its saturation temperature,

The efficiencies of the internal nozzle and diffuser of ejector are considered constant $\left(\eta_{N}=\eta_{D}=0.7\right)$.

The whole system is modeled in MATLAB software and it is divided into 3 main subsystems: solar collector subsystem, ejector cycle subsystem and vapor-compression refrigeration cycle subsystem. 


\subsection{The Solar Collector Subsystem}

The useful heat gained by the solar collector, is calculated by the Hottel-WhillierBliss equation:

$$
Q_{u}=A F\left[I(\tau \alpha)_{e}-U_{L}\left(T_{i n}-T_{a}\right)\right]
$$

The energy efficiency of the solar collector can be expressed as,

$$
\eta_{s c}=\frac{Q_{u}}{A_{s c} I}=F_{R}(\tau \alpha)_{e}-\frac{F_{R} U_{L}\left(T_{i n}-T_{a}\right)}{I}
$$

\subsection{The Ejector Refrigeration Cycle Subsystem}

According to Fig. 2a, generally, the ejector consists of four parts: a nozzle section for primary flow and a section chamber for the secondary flows, a mixing section for the primary and secondary flows and the diffuser section for the mixed fluid to recompress to the previous pressure [10]. Figure $2 \mathrm{~b}$ represents the $\mathrm{p}$-h diagram of the ejector refrigeration cycle.

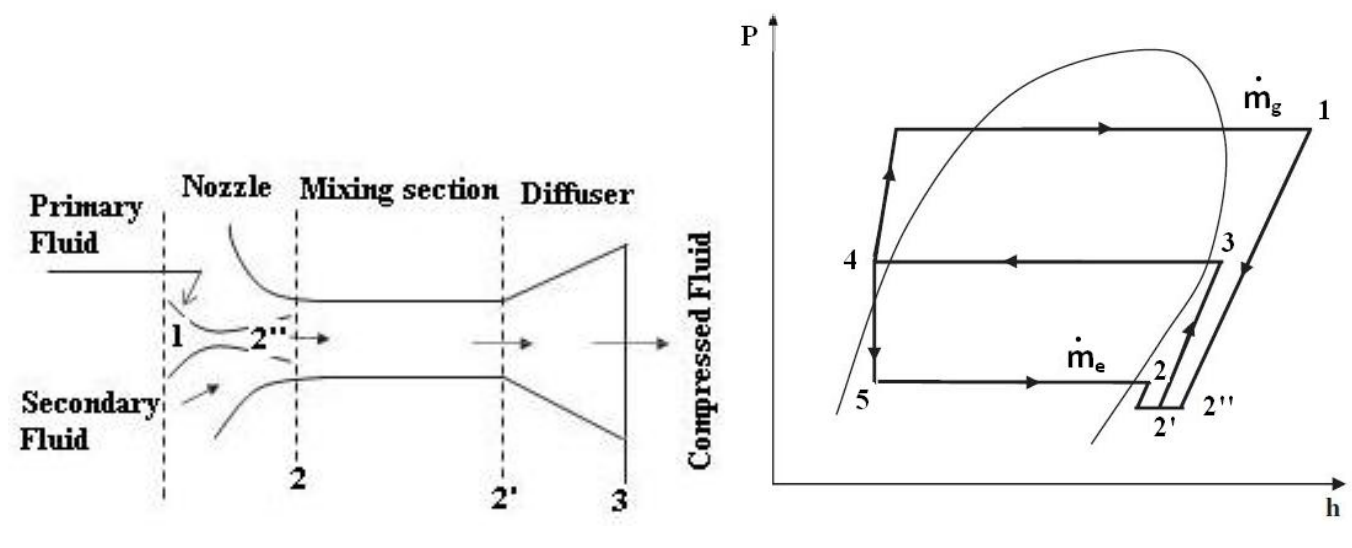

(a)

(b)

Fig. 2: (a) Schematic of the ejector system; (b) p-h diagram of the ejector refrigeration cycle.

There are several parameters used to describe the performance of an ejector. For refrigeration cycles, the most important parameters are defined in terms of entrainment and compression ratios. The mentioned parameters can be written as in [12]

$$
\begin{aligned}
& \omega=\frac{m_{e}}{m_{g}} \\
& r_{p}=\frac{P_{c}}{P_{e}}
\end{aligned}
$$

Using mass balance, energy balance and momentum equations for mixing section of the ejector as a control volume, the following correlations may be derived,

Mass balance: $m_{m \imath x}=\dot{m}_{e}+\dot{m}_{g}$

Energy balance: $\left(\dot{m}_{e}+\dot{m}_{g}\right) h_{3}=\dot{m}_{e} h_{2}+\dot{m}_{g} h_{1}$

Momentum balance: $\left(\dot{m_{e}}+\dot{m}_{g}\right) v_{m i x}=\dot{m}_{e} v_{e}+\dot{m}_{g} v_{g}$

From the energy conservation equation for the internal nozzle and diffuser of the ejector, the velocities of the primary, secondary and mixed fluids are as follows, 


$$
h_{3}-h_{\dot{2}}=v_{\text {mix }}^{2} / 2 ; h_{1}-h_{2 \prime}=v_{g}^{2} / 2^{2} ; h_{2}^{\prime}-h_{2}=v_{e}^{2} / 2
$$

According to the aforementioned equations the secondary fluid velocity is negligible, compared with the primary fluid, due to the small difference in enthalpy. Thus, the entrainment ratio equation will be stated as,

$$
\omega=\frac{\dot{m}_{e}}{\dot{m}_{g}}=\frac{v_{g}}{v_{\text {mix }}}-1=\left(\frac{h_{1}-h_{2^{\prime \prime}}}{h_{3}-h_{\dot{2}}}\right)^{1 / 2}-1
$$

\subsection{Vapor Compression Refrigeration Cycle Subsystem}

The conventional vapor compression refrigeration cycle is considered for the investigation. The system consists of an evaporator, a condenser, a thermostatic expansion valve and a compressor.

\subsection{System Efficiencies}

For the solar-driven refrigeration system, the performance can be demonstrated as the product of the COP and solar collector efficiency $\left(\eta_{\mathrm{sc}}\right)$. This term is described as [12]

$$
S T R=\frac{Q_{e}}{I A}=\frac{Q_{e}}{Q_{g}} \times \frac{Q_{g}}{I A}=C O P \times \eta_{s c}
$$

The coefficient of performance (COP) of the system is defined as:

$$
C O P=\frac{Q_{e}}{Q_{g}+W_{\text {pump }}+W_{\text {comp }}}
$$

The exergy efficiency of the system, $\eta_{\mathrm{ex}}$, is expressed as the COP of the refrigeration cycle divided by the Carnot COP of the actual system as [10]

$\eta_{\text {ex }}=\frac{C O P}{\operatorname{COP}_{\text {carnot }}}$

where $\mathrm{COP}_{\text {carnot }}$ is defined as,

$$
\text { COP } \text { carnot }=\frac{T_{e}}{T_{c}-T_{e}} \cdot \frac{T_{g}-T_{C}}{T_{g}}
$$

\section{WORKING FLUID SELECTION}

Xiangjie Chen, et al. [13] reviewed the requirements which should be taken into consideration for choosing a working fluid. Some of the most important parameters are as follows:

- The fluid should have a large latent heat of vaporization in order to minimize the circulation rate per unit of cooling capacity.

- The fluid pressure at the generator temperature should not be too high in order to avoid heavy construction of the pressure vessel and to minimize the power required by pump.

- Working fluid with smaller value of molecular mass requires comparatively larger ejectors for the same system capacity. The difficulties of constructing small-scale ejector components should be considered. However, higher molecular mass fluid leads to an increase in entrainment ratio and ejector efficiency.

- Environmental impact: the fluid should be environmental friendly with relatively low ozone depletion potential (ODP) and global warming potential (GWP). 
- Safety: the fluid should be chemically stable, non-toxic, non- explosive, and noncorrosive.

- The refrigerants, such as R114, R141b, R123, R152a, R245fa, R600a, R365mfc and R1234ze(e) are used as working fluids to simulate the ejector refrigeration cycles and R1234yf is considered as refrigerant for the vapor compression cycle analysis.

\section{RESULTS AND DISCUSSION}

Some properties of the selected refrigerants, which are important for working fluid selection, are presented in Table 1 . The thermodynamic properties are extracted from the REFPROP 8.0 software.

Table 1: Properties of refrigerants used in this investigation.

\begin{tabular}{|c|c|c|c|c|c|c|c|c|}
\hline & $\begin{array}{c}\text { Mol. } \\
\text { Wt. } \\
\text { (kg/mol) }\end{array}$ & $\begin{array}{c}\mathbf{T}_{\text {critical }} \\
\left({ }^{\circ} \mathbf{C}\right)\end{array}$ & $\begin{array}{c}\text { Latent heat } \\
\text { of } \\
\text { vaporization } \\
\text { at } 0{ }^{\circ} \mathbf{C} \\
(\mathbf{k j} / \mathbf{k g})\end{array}$ & $\begin{array}{c}\text { Pressure at } \\
\text { generating } \\
\text { temp. } \\
\left(95^{\circ} \mathrm{C}\right)\end{array}$ & GWP & ODP & $\begin{array}{l}\text { Application } \\
\text { (in this study) }\end{array}$ & $\begin{array}{l}\text { Flammability/ } \\
\text { ASHREA Class }\end{array}$ \\
\hline R114 & 170.9 & 145.7 & 137.19 & 1282.8 & 9200 & 0.85 & Ej. cycle & $\mathrm{NO} /-$ \\
\hline $\mathrm{R} 141 \mathrm{~b}$ & 117.0 & 204.2 & 237.60 & 604.79 & 630 & 0.1 & Ej. cycle & NO/- \\
\hline R123 & 152.89 & 183.7 & 181.44 & 701.42 & 93 & 0 & Ej cycle & NO/- \\
\hline $\mathrm{R} 152 \mathrm{a}$ & 66.0 & 113.5 & 307.11 & 3179.1 & 140 & 0 & Ej. cycle & YES/A2 \\
\hline $\mathrm{R} 245 \mathrm{fa}$ & 134.0 & 154.0 & 204.47 & 1129.8 & 820 & 0 & Ej. cycle & $\mathrm{NO} /-$ \\
\hline R600a & 58.1 & 152.0 & 385.27 & 1382.5 & 3 & 0 & Ej. cycle & YES/A3 \\
\hline $\mathrm{R} 365 \mathrm{mfc}$ & 148.07 & 186.8 & 206.26 & 519.51 & 890 & 0 & Ej. cycle & $?$ \\
\hline R1234ze(e) & 114.0 & 109.3 & 184.09 & 2739.0 & $<10$ & 0 & Ej. cycle & $?$ \\
\hline R1234ze(z) & 114.0 & 153.7 & - & 3100.0 & $<10$ & 0 & Ej. cycle & $?$ \\
\hline R1234yf & 114.0 & 94.7 & 163.29 & supercritical & 4 & 0 & Vc cycle & NO/- \\
\hline $\mathrm{R} 134 \mathrm{a}$ & 102.0 & 101.1 & 198.60 & 3591.2 & 1400 & Low & Vc cycle & $\mathrm{NO} /-$ \\
\hline
\end{tabular}

*: properties are taken from (Brown et al., 2009)

Figures 3 and 4 show the comparative results of COP and exergy efficiencies of the selected refrigerants in the conventional and the new model cycles. It is observed that in conventional cycle fluids, R114 and R1234ze(e) yield higher COP and exergy efficiency at the same operating conditions compared with the other refrigerants. This order is followed by R123, R245fa, R365mfc, R141b, R152a and R600a. In the new configured cycle, both COP and exergy efficiency of R1234ze(e) are the highest and it performs better than R114 in spite of the conventional cycle. In the new cycle with R1234ze(e) the values of COP and exergy efficiency are on an average $2 \%$ and $4 \%$ higher than that of $\mathrm{R} 114$, respectively. It is shown in the figures that R152a and R600a yield lower COP among the other refrigerants; it may be due to their low molecular weight and hence higher vapor pressure as presented in Table 1. In addition, the COP and exergy efficiency of cycle 2 is higher than that of the conventional system for all refrigerants. 


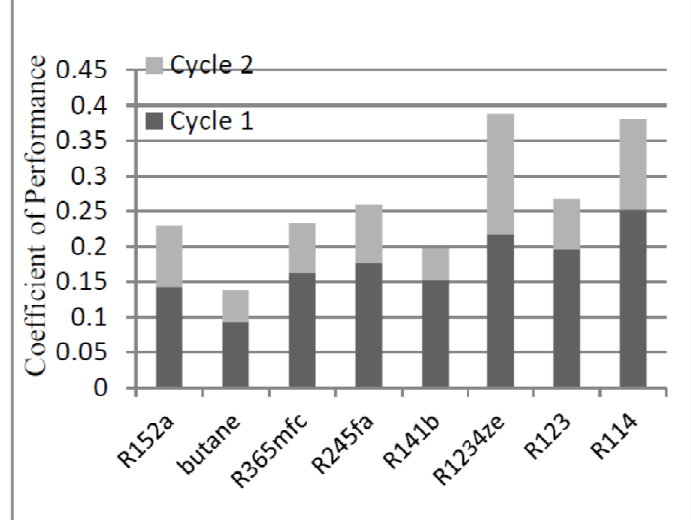

Fig. 3: Comparison of system performance of several selected refrigerants.

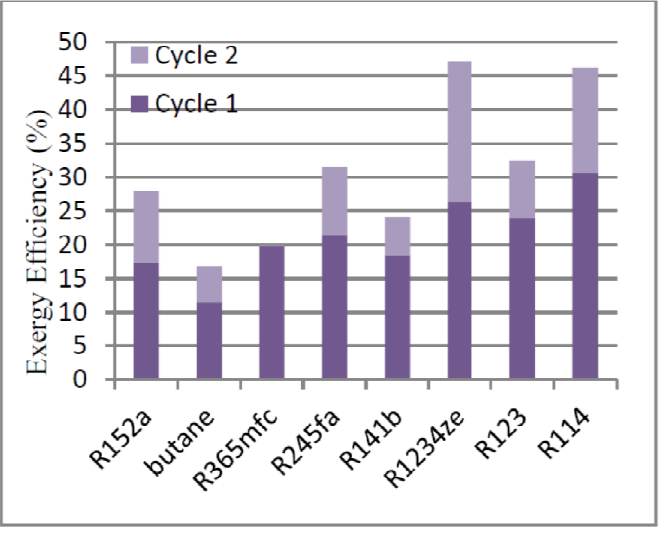

Fig. 4: Comparison of exergy efficiency of several selected refrigerants.

Since R114 is forbidden due to its environmental effect (GWP=9200 and ODP=0.85), so it is not suitable to be used in the solar combined ejector-vapor compression refrigeration cycles. The working fluid, R1234ze(e), is obviously an interesting refrigerant to replace R114. The following analysis will be based on the comparison of new and conventional cycles and the effects of the operating conditions using R1234ze(e) as the working fluid. Note that R1234yf is not appropriate to be used in the ejector-vapor compression cycle; because the generating temperature in this cycle may reach $100^{\circ} \mathrm{C}$, whereas the critical temperature of $\mathrm{R} 1234 \mathrm{yf}$ is below $100^{\circ} \mathrm{C}$ as shown in Table 1 . The new refrigerant, R1234ze(z) seems to be a suitable replacement of R114 in the solar ejector refrigeration cycle, since it was demonstrated that R-1234ze(z) deserves further considerations as a possible R-114 replacement by Brown et al., 2009 [3] and it may be more efficient than R1234ze(e) in the considered system, due to its higher critical temperature.

Figures 5 and 6 represent the effects of the evaporating and condensing temperature on COP for the conventional and the new cycle model presented in this study with R1234ze(e) as working fluid. By increasing $\mathrm{T}_{e}$, COPs of both cycles increase at an equal operating condition $\left(\mathrm{T}_{\mathrm{g}}=95^{\circ} \mathrm{C}\right.$ and $\left.\mathrm{T}_{\mathrm{c}}=50^{\circ} \mathrm{C}\right)$ because increasing the evaporative temperature, the secondary flow increases, and then the entrainment ratio increases as well. Thus, the values of COP will be enhanced by the increase in the entrainment ratio. On the other hand, raising $\mathrm{T}_{\mathrm{e}}$ leads to a decrease in the latent heat of vaporization and cooling capacity. As a result, the overall COP will be increased. The trend of this graph is in agreement with the result of the theoretical work done by L. Kairouani, et al., [10]. According to Fig. 6, an increase of $\mathrm{T}_{\mathrm{c}}$ causes a decrease in $\mathrm{COP}$ at $\mathrm{T}_{\mathrm{e}}=4^{\circ} \mathrm{C}$. According to equation (4), by increasing $\mathrm{T}_{c}$, the compression ratio of the ejector refrigeration cycle increases and a high amount of $r_{p}$ causes a reduction in COP as shown in Fig.7. This result is in agreement with the results of [14]. It is found that the value of COP for the new presented cycle with internal heat exchanger is approximately $37 \%$ higher than that of the conventional one. Also, this figure shows the COP is highly affected by condensing temperature.

Figure 7 represents the effect of evaporating temperature on compression ratio, entrainment ratio and COP, at constant condensing and generating temperature $\left(\mathrm{T}_{\mathrm{g}}=95^{\circ} \mathrm{C}\right.$ and $\mathrm{T}_{\mathrm{c}}=50^{\circ} \mathrm{C}$ ). Also, it shows that, by increasing entrainment ratio and decreasing compression ratio, the value of $\mathrm{COP}$ will be increased, which is a reason for the ascending 
and descending trends of Fig. 5 and Fig. 6. Increasing of the entrainment ratio may be due to the increase of the secondary flow velocity by raising evaporator temperature. By decreasing the compression ratio, the entrainment ratio and then the secondary fluid flow from the intercooler would be increased. It causes an increase in refrigerating capacity. Hence, COP increases as compression ratio decreases, which is a reason for the COP descending trend of Fig. 6. A. Mani and T. Sankarlal [15] have found a similar behavior in an experimental investigation of ejector refrigeration system.

The effect of evaporating temperature on exergy efficiency is shown in Fig. 8 for the conventional and the presented cycle with R1234ze(e) as working fluid. It is found that the behavior of exergy efficiency versus evaporating temperature is similar to the COP behavior as shown in Fig. 5. Also, at fixed generating and condensing temperature, the exergy efficiency of cycle 2 is higher than cycle 1 by $40 \%$.

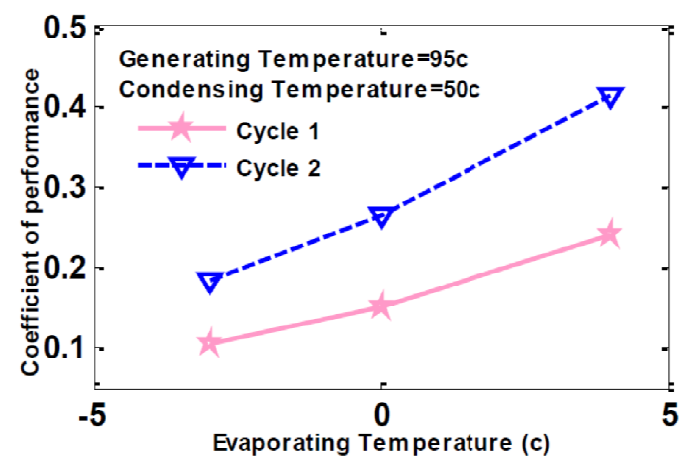

Fig. 5: Variation of coefficient of performance versus evaporating temperature for conventional and the presented cycle with R1234ze(e).

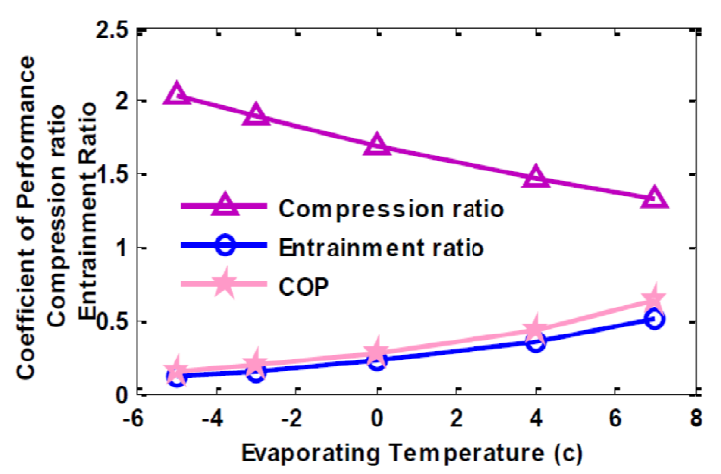

Fig. 7: Variation of compression ratio, entrainment ratio and COP with evaporating temperature, using R1234ze(e).

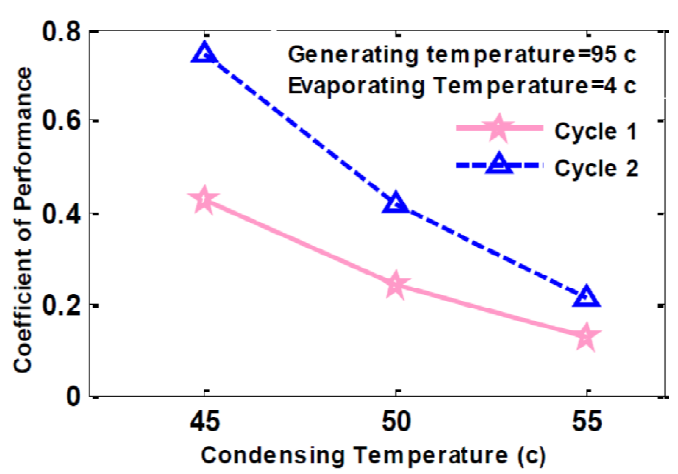

Fig. 6: Variation of coefficient of performance versus condensing temperature for conventional and the presented cycle with R1234ze(e).

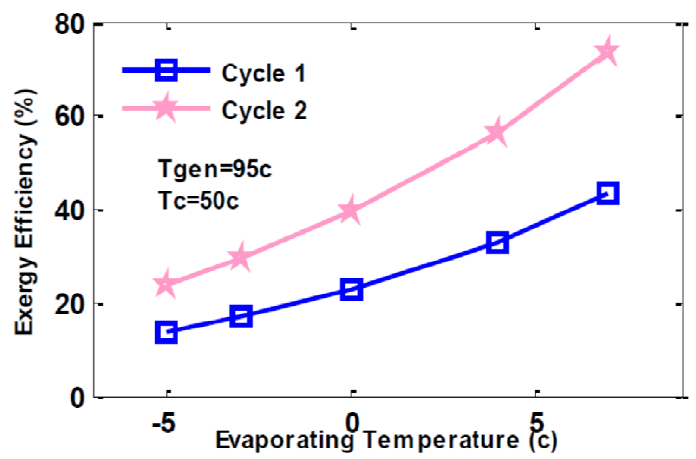

Fig. 8: Variation of exergy efficiency versus evaporating temperature for conventional and the presented cycle in this study with R1234ze(e).

In Fig. 9 the performance of R1234ze(e) is shown, when it is used in both cycles 1 and 2. The system thermal ratio (STR) depends on the COP and the efficiency of the solar collector, as expressed in (2). As mentioned in the work of Jianlin Yu, et al., [16] the generating pressure is directly related to the generating temperature $T_{g}$, and increasing $T_{g}$ 
also produces an obvious increase of the generating pressure. Clearly, the entrainment ratio of the ejector refrigeration cycle tends to increase with $T_{g}$. Therefore, increasing the entrainment ratio improves the COP of the system for a higher generating temperature. According to Fig. 9 the solar collector efficiency decreases and COP of the system is increased, when the generating temperature increases. Thus, the STR remains constant at different generating temperatures.

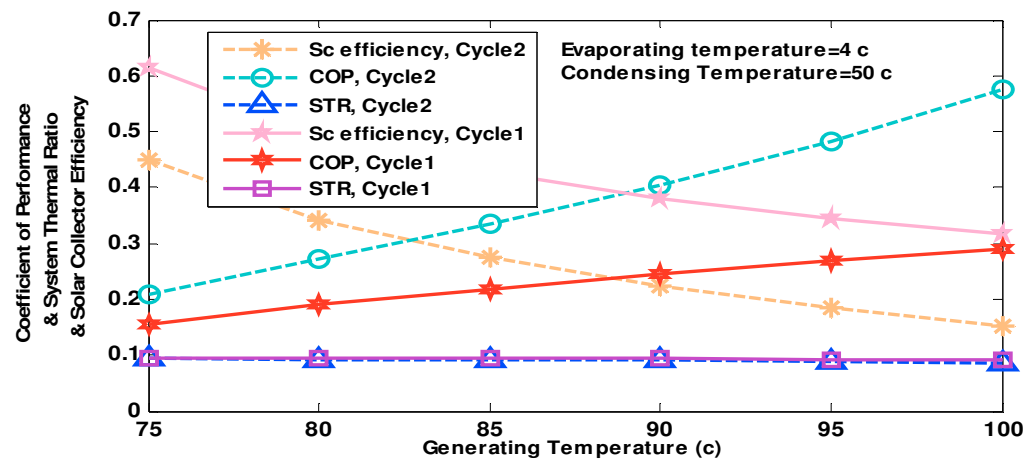

Fig. 9: Effect of generating temperature on COP, system thermal ratio and solar collector efficiency for conventional and the presented cycle with R1234ze(e).

The solar collector efficiency is dependent on the choice of the collector type and the required heat of generating process. It is noticed that the solar collector efficiency of cycle 2 is lower than that of cycle 1 . It must be due to its lower requirements of generating heat, since an internal heat exchanger is installed before entering fluid to generator in new model.

According to Figs. 5, 6 and 9, the influence of condenser temperature changes on the ejector refrigerant system is greater than the evaporation temperature and generator temperature, HuiFan Zheng et al., [17] have the same conclusion. Thus, the value of coefficient of performance may be expressed as a function of generating, condensing and evaporating temperatures.

\section{CONCLUSION}

The performance of a cycle with internal heat exchanger was compared with the conventional cycle. The variation of COP, solar thermal ratio (STR), exergy efficiency $\left(\eta_{e x}\right)$, entrainment ratio $(\omega)$ and compression ratio $\left(\mathrm{r}_{\mathrm{p}}\right)$ were investigated by varying the generating temperature, condensing temperature and evaporating temperature. Also, the effects of working fluids were investigated on the system performance. The following conclusions are made:

- The results indicate that the variation in COP values is highly affected by the variety of the applied refrigerants. As shown in the figures, the refrigerants R114 and R1234ze perform very well. The better performance is followed by R123, R245fa, R365mfc, R141b and R152a and R600a, respectively.

- In the conventional cycle, the COP and exergy efficiency of R114 is higher than R1234ze(e).

- The COP and exergy efficiency values of both cycles are increased by increasing the evaporator temperature when R1234ze(e) is used as working fluid.

- By increasing the generating temperature, COP values increase. Also, the COP value is decreased by increasing the condensing temperature. 
- By increasing the evaporator temperature the compression ratio $\left(r_{p}\right)$ is decreased and the entrainment ratio $(\omega)$ is increased. This behavior leads to an increase in COP.

- The refrigerant R1234ze(z) may be more efficient than R1234ze(e) for use in the solar ejector refrigeration cycles.

- In all operating conditions, the cycle with internal heat exchanger has higher COP compared to the conventional cycle. However, the solar collector efficiency of the cycles equipped with internal heat exchanger (the new cycle) will be lower due to their lower requirements of generated heat.

Distinguishing the locations where the most non-idealities occur, is possible to enhance the performance of the system so, analysis of the component exergy destruction would be important and has the potential for future work.

\section{REFERENCES}

[1] Brown J.Steven, Zilio Claudio, Cavallini Alberto: "Thermodynamic properties of eight fluorinated olefins." International Journal of Refrigeration 33 (2010), 235-41.

[2] Nielsen O.J., Javadi M.S., Sulbaek Andersen M.P., Hurely M.D., Wallington T.J., Singh R.: "Atmospheric chemistry of $\mathrm{CF} 3 \mathrm{CF}=\mathrm{CH} 2$; Kinetic and mechanisms of gas-phase reactions with $\mathrm{Cl}$ atoms, $\mathrm{OH}$ radicals and O3." Chemical Physics Letter 439: 2007: 18-22.

[3] Brown J.Steven, Zilio Claudio, Cavallini Alberto: "The fluorinated olefin R-1234ze(z) as a high- temperature heat pumping refrigerant." International Journal of Refrigeration 32 (2009): 1412-22.

[4] Huang, B. J., Chang, J. M., Petrenko, V. A. and Zhuk, K. B.: A "Solar Ejector Cooling System Using Refrigerant R141b.” Solar Energy 64 (1998): 223-226.

[5] Bejan, A., Vargas, J. V. C. and Sokolov, M.: "Optimal Allocation of a Heat-Exchanger Inventory in Heat Driven Refrigerators." International Journal of Heat and Mass Transfer 38 (1995): 2997-3004.

[6] Arbel, A. and Sokolov, M.: "Revisiting Solar-Powered Ejector Air Conditioner- the Greener the Better." Solar Energy 77 (2004):57-66.

[7] Wolpert, J. L., Riffat, S. B. and Redshaw, S: "Prototype for a Novel Solar Powered Ejector Air Conditioning System in Mazunte, Mexico. ISES Solar World Congress." Solar Energy for a Sustainable Future: 2003;

[8] Rusly, E., Charters, W. W. S., Ooi, A. and Aye, L: "Combined Solar and Electric System for Space Cooling." The 7th International Energy Agency Heat Pump Conference: 2002.

[9] Pridasawas, W. and Lundqvist, P: "Working Fluid Selection for an Ejector Refrigeration Cycle." International Institute of Refrigeration: Stockholm, Sweden.

[10] E. Nehdi, L. Kairouani, M. Elakhdar: "A solar ejector air-conditioning system using environment-friendly working fluids." International of Energy Research 32 (2008): 11941201.

[11] Jin Hua Wang, J.H. Wu, S.S. Hu and B.J. Huang: "Performance of ejector cooling system with thermal pumping effect using R141b and R365mfc." Applied Thermal Engineering 29 (2009): 1904-12.

[12] Wimolsiri Pridasawas: "Solar-Driven Refrigeration Systems with Focus on the Ejector Cycle. "PhD Thesis, KTH Industrial Engineering and Management; 2006.

[13] Xiangjie Chen, Siddig Omer, Mark Worall, Saffa Riffat: "Recent Developments In Ejector Refrigeration Technologies." Renewable and Sustainable Energy Reviews 19 (2013): 629651

[14] Sandeep Kashyap, R.C. Gupta: "Theoretical Study of Ejector Refrigeration System with Working Fluid R410a." International Journal of Engineering Science and Technology 8 (2011): 6508-13. 
[15] A.Mani, T. Sankarlal: "Experimental Investigation on Ejector Refrigeration System with Ammonia." Renewable Energy 32 (2007): 1403-13.

[16] Jianlin Yu, Zhenxing Du: "Theoretical Study of a Transcritical Ejector Refrigeration Cycle with Refrigerant R143a." Renewable Energy 35 (2010): 2034-39.

[17] Hui Fan Zheng, YaoHua Liang, Lan Yu Haung: "Analysis of Entrainment Ratio about Solar Ejector Refrigerant System.” Energy Procedia 16 (2012) 16: 516-21.

\section{NOMENCLATURE}

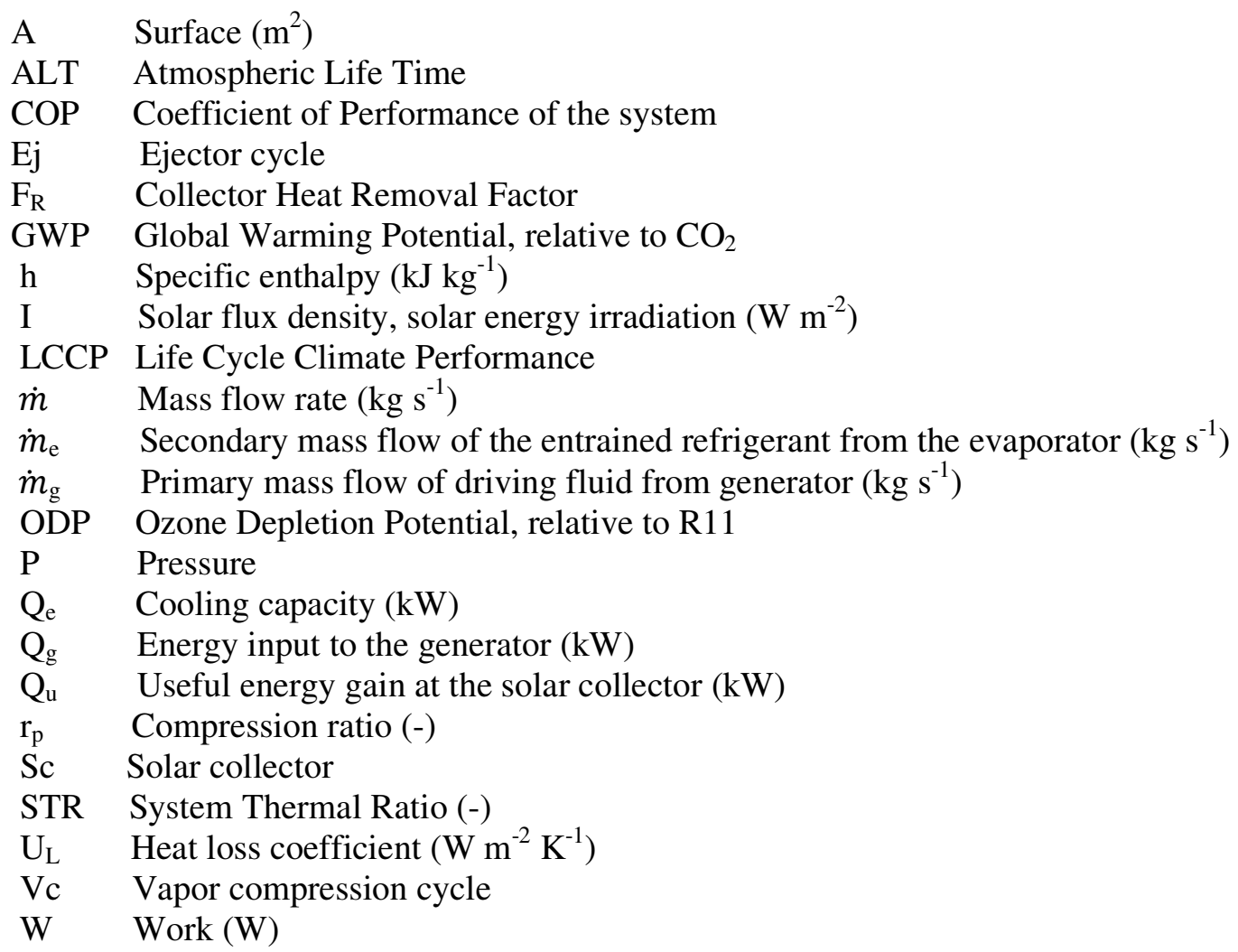

Greek symbols

$\eta \quad$ Efficiency (-)

$(\tau \alpha)_{e}$ Effective transmittance-absorbance product

$v \quad$ velocity $\left(\mathrm{m} \mathrm{s}^{-1}\right)$

$\omega$ entrainment ratio

\section{Subscripts}

a ambient

c condenser

comp compressor

d diffuser

e evaporator

ex exergy

g generator

in inlet

IC intercooler

IHX internal heat exchanger 